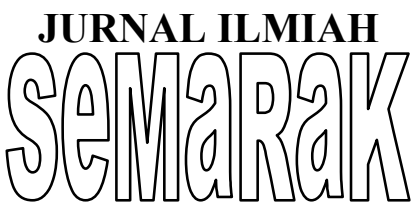

Jurnal Semarak,Vol. 1,No.3,Oktober 2018 , Hal (142-157)

@.Prodi Manajemen Fakultas Ekonomi Universitas Pamulang

\title{
PENGARUH PROMOSI DAN PENGEMBANGAN PRODUK TERHADAP PENINGKATAN HASIL PENJUALAN
}

(Studi PT. Baja Perkasa Jakarta)

\author{
Jasmani \\ Staf Pengajar Fakultas Ekonomi Universitas Pamulang \\ Email: djasmany@yahoo.com
}

Fokus dari riset ini yaitu dalam rangka mengetahui keterhubunganan antara kegiatan promosi dan pengembangan produk terhadap peningkatan hasil penjualan pada PT.Baja Perkasa.

Dalam pengumpulan data digunakan metode explanatory research dan analisis inferensian dengan sampiling jenuh sebanyak 55 responden. Jenis analisis yang dipakai menggunakan penggabungan kualitatif dan kuantitatif atau Mix Method .

Adapun hasil penelitian disimpulkan sebagai berikut:Variable promosi memiliki hubungan yang positive dan significant terhadap peningkatan hasil penjualan dengan nilai correlation sebesar 0.487 . Nilai coefficient determination sebesar $23,7 \%$. Uji hipotesis sebesar Prob.Sig $0.000<0.050$.Variable pengembangan produk memiliki hubungan yang positive dan significant terhadap peningkatan hasil penjualan dengan nilai correlation sebesar 0,532 dan coefficient determination sebesar 28.30\%. Uji hipotesis sebesar Prob.Sig $0.000<0.050$.Variable promosi dan pengembangan produk secara simultan memiliki hubungan yang positive dan significant terhadap peningkatan hasil penjualan dengan nilai correlation sebesar 0,609 dan coefficient determination sebesar 37\%. Uji hipotesis sebesar Prob.Sig $0.000<0.050$.

\section{Kata Kunci: Kegiatan Promosi, Pengembangan Produk dan Peningkatan Hasil Penjualan}

\section{ABSTRACT}

The focus of this research is in order to know the relationship between promotional activities and product development towards increasing sales results at PT. Perkasa Perkasa.

In collecting data used explanatory research methods and inferential analysis with saturated skills as many as 55 respondents. The type of analysis used uses a combination of qualitative and quantitative or Mix Method.

The results of the study are summarized as follows: Variable promotions have a positive and significant relationship to the increase in sales results with a correlation value of 0.487 . The coefficient of determination is $23.7 \%$. Hypothesis testing is equal to Prob. Sig 0,000 <0.050.

Variable product development has a positive and significant relationship with the increase in sales results with a correlation value of 0.532 and a coefficient of $28.30 \%$. Hypothesis testing is equal to Prob. Sig 0,000<0.050.

Variable promotions and product development simultaneously have a positive and significant relationship to the increase in sales results with a correlation value of 0.609 and a coefficient of determination of 37\%. Hypothesis testing is equal to Prob. Sig 0,000 $<0.050$.

Keywords: Promotion Activities, Product Development and Increased Sales Results

\section{PENDAHULUAN}

\section{A. Latar Belakang Masalah}

Tingkat intensitas daya saing pada industri manufacturing sekarang sangat ketat, terutama dalam produk baja 
JURNAL

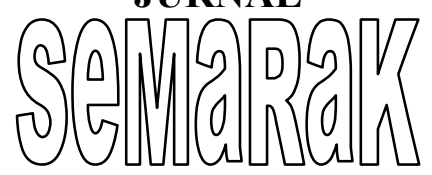

P-ISSN 2615-6849 E-ISSN 2622-3686

Semarak,Vol. 1, No.3,Oktober 2018, Hal (1-20)

@Prodi Manajemen Fakultas Ekonomi Universitas Pamulang galvalum dimana masing-masing industri berusaha mengoptimalkan kapasitas industri terpasang. Banyak produsen dalam upaya menggaet pelanggan dilakukan dengan memanfaatkan kualitas peorduk yang dihasikan dengan iklan, surat kabar maupun media lainnya atau dengan packing yang lebih praktis dan berbeda dari lainnya.

PT.Baja Perkasa setiap tahun selalu mengevaluasi produknya, dimana produknya terkait mutu dan varians yang diproduksi, jangan sampai pelanggan merasa tidak tertarik dan tidak ada pengembangan produk. Sebagai pelaku industri baja galvalum yang memiliki bahan baku baja zinc coated dengan chrome zinc dengan kandungan alluminium coil, lapisan (coating) terdiri dari alluminium coil, $43.50 \%$ zinc dan $1.5 \%$ cilicont. Sifat alluminium coil yang tahan karat dan kombinattion karat dengan zinc keras membuat kombinasi kedua material lebih tahan karat, lebih kuat dan ringan. Hal ini memungkinkan perusahaan melakukan berbagai pengembangan produk yang terkait dengan bahan baku baja galvalum. Mengingat keberadaan suatu produk perlu diinformasikan keluar, peranan promosi menjadi penting dilakukan dalam rangka meningkatkan penawaran produk dan pembelian konsumen.
Dengan melihat pentingnya promosi, sangat tepat bagi perusahaan untuk mempertimbangkan konsep iklan yang benar-benar tepat sasaran, sehingga dapat mendukung kesuksesan perusahaan. Persaingan di antara produsen yang mengiklankan produk atau layanan mereka menggunakan iklan media tidak hanya berguna untuk mengingatkan dan mendorong konsumen untuk membeli produk atau layanan, tetapi juga dapat digunakan sebagai karakteristik yang dapat membedakan antara satu produsen dan produsen lain.

Hal ini selaras dengan pendapat Kotler and Amstrong (2014) "Promosi adalah aktivitas yang mengkomunikasikan keunggulan produk dan membujuk pelanggan untuk membeli produk itu".

Definisi ini dapat diartikan bahwa dengan mengadakan kegiatan promosi, produsen dapat menyampaikan berbagai informasi kepada konsumen. Promosi juga dapat membantu memperkenalkan konsumen pada suatu produk untuk dapat memilih produk yang mereka inginkan melalui pesan yang membujuk, mengingatkan, menginformasikan, dan mendorong konsumen untuk membeli produk yang ditawarkan.Agar tetap dapat bersaing dalam industri yang sejenis, PT. Baja Perkasa harus berupaya melakukan pengembangan produk baik mengenai kualitas produk, kemasan atau packing, 


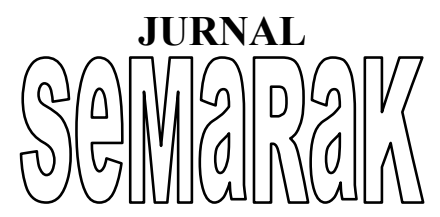

Semarak,Vol. 1, No.3,Oktober 2018, Hal (1-20)

@Prodi Manajemen Fakultas Ekonomi Universitas Pamulang

maupun harga. Hal ini selaras dengan pendapat Yamit (2013) bahwa "Pengembangan produk (Product Development) adalah upaya perusahaan untuk menciptakan produk baru, memperbaiki produk lama atau memodifikasi produk lama agar dapat memenuhi tuntutan pasar dan selera pelanggan".

\section{B. Rumusan Masalah}

1. Adakah hubungan secara parsial dari promosi terhadap peningkatan hasil penjualan

2. Adakah hubungan secara parsial dari pengembangan produk terhadap peningkatan hasil penjualan

3. Bagaimana hubungan secara simultan dari promosi dan pengembangan produk terhadap peningkatan penjualan.

\section{Tujuan Penelitian}

1. Untuk mengetahui hubungan antara promosi terhadap peningkatan hasil penjuan.

2. Untuk mengetahui hubungan antara pengembangan produk terhadap peningkatan hasil penjuan.

3. Untuk mengetahui hubungan antara promosi dan pengembangan produk secara simultan terhadap peningkatan hasil penjuan.

\section{Manfaat Dari Penelitian}

1. Manfaat Secara Teoritis.

Dapat menambah wawasan dan dapat digunakan sebagai kajian mendalam menajemen pemasaran dengan memberikan informasi bagi pembaca sehingga dapat dijadikan sebagai bahan referensi bagi yang memerlukan.

2. Manfaat Secara Praktis.

Mampu memberikan sumbangsih dan masuk positive pada pihak manajemen dalam mengambil kebijakan terkait dengan segmen pasar yang menjadi target penjualan produk.

\section{KAJIAN PUSTAKA}

\section{A. Pemasaran}

Menurut pendapat Philip Kotler (2014), "Pemasaran adalah mengindentifikasi dan memenuhi kebutuhan manusia dan sosial. Salah satu definisi yang baik dan singkat dari pemasaran adalah memenuhi kebutuhan dengan cara yang menguntungkan".

Lebih lanjut Kotler dan Keller (2014) menjelaskan "Pemasaran adalah suatu fungsi organisasi dan serangkaian proses untuk menciptakan, mengkomunikasikan, dan memberikan nilai kepada pelanggan dan untuk mengelola hubungan pelanggan dengan cara yang menguntungkan organisasi dan pemangku kepentingannya".

\section{B. Promosi}

Upaya yang dilakukan perusahaan dalam memperkenalkan atau memberikan informasi kepada masyarakat maupun pelanggannya. Promosi dilihat sebagai arus informasi satu arah atau kegiatan dalam 


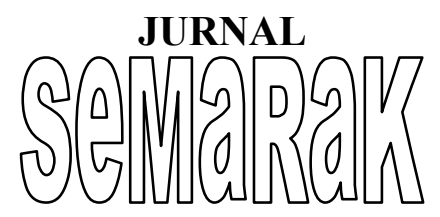

P-ISSN 2615-6849 E-ISSN 2622-3686

Semarak,Vol. 1, No.3,Oktober 2018, Hal (1-20)

@Prodi Manajemen Fakultas Ekonomi Universitas Pamulang membujuk pelanggan agar pelanggan mau melakukan pembelian dan proses transaksi.

Proses ini sangat penting karena promosi dapat memberikan informasi yang dapat langsung dipahami oleh pembeli dan akhirnya proses pembelian.

Menurut Stanton

berpendapat bahwa "Pemasaran sebagai keseluruhan intern yang berhubungan dengan kegiatan maupun usaha yang memiliki tujuan untuk merencanakan menentukan harga, mempromosikan dan mendistribusikan barang dan jasa yang akan memuaskan kebutuhan pembeli baik pembeli yang ada, maupun pembeli yang potensial". Sedangkan menurut Suryadi (2011) mendefinisikan "Promosi adalah serangkaian kegiatan untuk mengkomunikasikan dan menyakinkan orang tentang produk tersebut dan mengikat pikiran dan pasarannya dalam suatu wujud loyalitas pada produk".

Adapun menurut Swastha dan Irawan (2012) "Suatu perusahaan dalam menjalankan kegiatan promosi ada baiknya mengetahui apa yang menjadi tujuan diadakan promosi terebut".

Menurut Kotler dan Keller (2014) memiliki pendapat "Bauran komunikasi pemasaran (Marketing Mix) terdiri dari delapan model komunikasi utama, yaitu: melalui iklan (adversiting), promosi penjualan (promosi penjualan), acara dan pengalaman, hubungan masyarakat dan publisitas, pemasaran interaktif interaktif, dari mulut ke mulut pemasaran, penjualan pribadi ". Inilah yang dijadikan sebagai indikator dalam penelitian ini.

C. Pengembangan Produk (Product

\section{Development)}

Pengembangan produk sangat erat kaitannya dengan proses produksi, yaitu pekerjaan berjenjang yang membutuhkan upaya manusia yang serius, pengorbanan besar, dan kekuatan yang terpusat di lingkungan tertentu untuk mewujudkan kegunaan bahan yang handal. Upaya produsen untuk mendapatkan masahah maksimum dapat terwujud jika produsen menerapkan persyaratan pasar yang lebih menarik untuk target pasar sasaran. Strategi pengembangan produk adalah strategi untuk mengembangkan produk baru yang terkait dengan produk yang sudah ada. Dalam menerapkan strategi pengembangan produk, perlu mempertimbangkan faktor-faktor penentu kapan strategi dapat diterapkan dengan benar, termasuk:

1. Memiliki cukup kemampuan dalam pengembangan

2. Produk live circle dan keberhasilan produk dimata pelanggan

3. Perkembangan teknologi

4. Persaingan produk di pasar.

5. Pertumbuhan industri.

Pengembangan produk tentu melibatkan modifikasi produk dengan 
menciptakan produk yang baru yang dapat dipasarkan pada pelanggan. Idenya untuk memenuhi kepuasan pelanggan produk baru sebagai hasil pengalaman positive mereka dengan tawaran awal perusahaan. Pengembangan produk, yaitu membuat produk baru oleh perusahaan untuk menggantikan produk yang sudah ada.

\section{Peningkatan Hasil Penjualan}

Menurut Kotler (2014) "Penjualan adalah bisnis yang terintegrasi untuk mengembangkan rencana strategis yang diarahkan pada upaya untuk memenuhi kebutuhan dan keinginan pembeli, untuk mendapatkan penjualan yang optimal".

Menurut Winardi (1992) "Penjualan adalah proses dimana penjual memuaskan segala kebutuhan dan keinginan pembeli agar dicapai manfaat baik bagi sang penjual maupun sang pembeli yang menguntungkan kedua belah pihak". Menurut Kamelia (2006) "Penjualan yang berhasil dicapai memalui jumlah produk atau merek suatu perusahaan yang terjual dalam suatu jangka waktu tertentu".

Menurut Kotler (2014) "Volume penjualan adalah suatu yang menandakan naik turunnya penjualan dan dapat dinyatakan dalam bentuk unit, kilo, ton atau liter". Indikator hasil penjualan terdiri atas : Harga produk, Informasi produk, Saluran distribusi, Kualitas produk dan Keuntungan perusahaan

\section{E. Kerangka Pemikiran}

Menurut Sugiyono (2014) "Kerangka berpikir adalah sintesa yang mencerminkan keterkaitan antara Variable yang diteliti dan merupakan tuntunan untuk memecahkan masalah penelitian serta merumuskan hipotesis penelitian yang berbentuk bagan alur yang dilengkapi penjelasan kualitatif". Menurut Sugiyono (2014) menjelaskan "Seorang peneliti harus menguasai teori-teori ilmiah sebagai dasar menyusun kerangka pemikiran yang membuahkan hipotesis". Promosi memiliki peran penting dalam pemasaran, promosi yang baik mencerminkan perusahaan konsisten menjaga mutu produk.

Pengembangan produk merupakan faktor yang juga penting dalam meningkatkan hasil penjualan. Keputusan melakukan pembelian/tidak membeli merupakan bagian dsri penilaian pelangan atas kualitas suatu produk. Menurut Yamit (2013) menyampaikan bahwa "Pada dasarnya pengembangan produk merupakan upaya perusahaan dalam menciptakan produk baru, memperbaiki produk lama atau memodifikasi produk lama agar selalu dapat memenuhi tuntutan pasar dan selera konsumen".

Menurut Basu Swastha (2011) "Hasil penjualan adalah jumlah barang dan atau jasa yang terjual pada proses pertukaran". Menurut Kotler (2014) “Konsep penjualan 


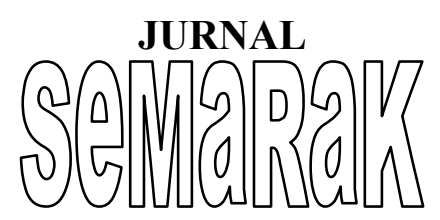

P-ISSN 2615-6849 E-ISSN 2622-3686

Semarak,Vol. 1, No.3,Oktober 2018, Hal (1-20)

@Prodi Manajemen Fakultas Ekonomi Universitas Pamulang

adalah konsumen, jika diabaikan, biasanya tidak akan membeli produk organisasi dalam jumlah yang cukup". Adapun kerangka berpikir sebagai berikut:

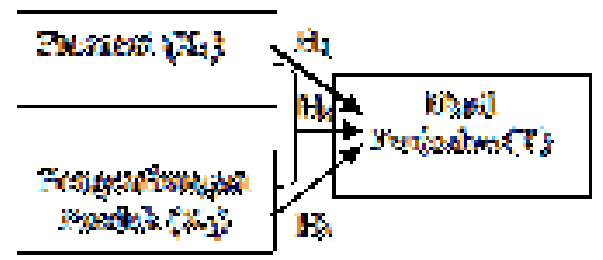

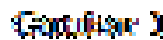

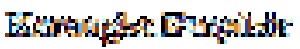

\section{F. Hipotesis Penelitian}

Menurut pendapat Sugiyono (2016) "Hipotesis merupakan jawaban sementara terhadap rumusan masalah. Karena sifatnya masih sementara, maka perlu dibuktikan kebenarannya melalui data empirik yang terkumpul". Hipotesis yang dibuat dalam penelitian ini meliputi:

H1: Diduga Terdapat hubungan yang positive dan significant antara promosi terhadap peningkatan hasil penjualan.

H2: Diguga terdapat yang positive dan significant dari pengembangan produk terhadap peningkatan hasil penjualan.

H3: Diduga terdapat hubungan yang positive dan significant secara simultan dari promosi dan pengembangan produk terhadap peningkatan hasil penjualan.

III. METODE DALAM PENELITIAN

\section{A. Obyek Penelitian}

$$
\text { Menurut Sugiyono }
$$
berpendapat "Obyek penelitian merupakan sasaran ilmiah untuk mendapatkan data". Dalam penelitian ini diadakan di PT. Baja Perkasa.

\section{B. Population \& Sampling}

\section{Population}

$$
\text { Menurut Sugiyono }
$$

berpendapat "Populasi adalah jumlah wilayah generalisasi yang terdiri atas obyek atau subyek yang mempunyai kualitas dan karakteristik yang ditetapkan oleh peneliti dan kemudian ditarik kesimpulannya". Dengan demikian populasi dalam penelitian ini yaitu pelanggan perusahaan.

\section{Sampling}

Sugiyono (2016) berpendapat "Sample adalah jumlah dan karakteristik yang dimiliki oleh populasi”. Sedangkan Suharsimi Arikunti (2010) "Sample adalah sebagian atau wakil populasi yang diteliti”. Dengan demikian Sample dapat menggunakan sampling jenuh dimana menurut Sugiyono (2014) sampling jenuh adalah teknik penentuan Sample bila semua anggota populasi digunakan sebagai Sample. Dalam penelitian ini berjumlah 55 responden.

\section{Teknik Pengumpulan Data}

Kegiatan dalam mengumpulkan data merupakan upaya dalam 


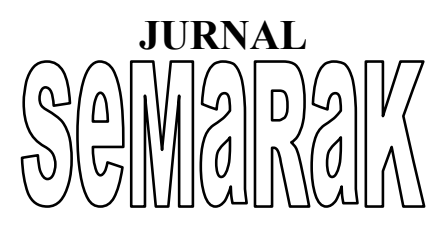

P-ISSN 2615-6849 E-ISSN 2622-3686

Semarak,Vol. 1, No.3,Oktober 2018, Hal (1-20)

@Prodi Manajemen Fakultas Ekonomi Universitas Pamulang memperoleh data untuk digunakan didalam pengukuran. Menurut Sugiyono (2016) "Metode pengumpulan data adalah cara ilmiah untuk mendapatkan data yang valid dengan tujuan dapat dibuktikan, dikembangkan pengetahuan sehingga dapat digunakan memecahkan dan mengantisipasi masalah".

\section{Primery Data}

Menurut Sugiyono (2014) "Data primer adalah sumber data yang langsung memberikan data kepada pengumpul data".

\section{Secundary Data.}

Pendapat dari Sugiyono (2014) "Data sekunder adalah sumber data yang tidak langsung yang memberikan data kepada pengumpul".

\section{Teknik Pengumpulan Data}

\section{Quesinner.}

Dilakukan dengan cara menyebar kuisioner kepada pelanggan yang lekakukan pembelian produk di PT.Baja Perkasa.

\section{Studi Pustaka.}

Penulis melakukan tinjauan literatur tentang pemasaran dan publikasi bukubuku dan materi yangberkaitan dengan persoalan yang menjadi pokok penelitian.

\section{E. Metode Analisis Data Penelitian}

Dalam penelitian ini menggunakan mix method berupa penggabungan antara kualitatif dan kuantitatif yang meliputi:

\section{Pengujian Instrument Penelitian}

\section{a. Pengujian Validitas Data}

Menurut Ghozali (2014) "Satu kuesioner dikatakan valid jika pertanyaan pada kuesioner mampu untuk mengungkapkan sesuatu yang akan diukur". Lebih lanjut dijelaskan "Uji validitas dilihat dari Table Item-Total Statistics". "Nilai tersebut dibandingkan dengan standar Chronbatch Alpha 0,30 dengan kriteria":

1) Apabila nilai Rca. $>$ Standar Alpha 0.30, maka Instrument valid.

2) Apabila nilai Rca. < Standar Alpha 0.30, maka Instrument tidak valid.

\section{b. Pengujian Reliabilitas Data}

Menurut Ghozali (2014) "Reliabilitas merupakan alat untuk menguji kekonsistenan jawaban responden atas pertanyaan di kuesioner. Kriteria yang digunakan apabila suatu alat ukur memberikan hasil yang stabil, maka disebut alat ukur itu handal". Lebih lanjut dijelaskan bahwa "Pengukuran dilakukan sekali dan reliabilitas dengan uji statistik Cronbach Alpha. Dalam pengukurannya one shot akan dilakukan dengan analisis Cronbach's Alpha".

\section{Pengujian Kelayakan Data}

Menurut Singgih (2014) "Sebuah model regresi akan digunakan untuk 
JURNAL

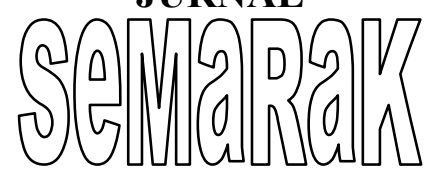

P-ISSN 2615-6849 E-ISSN 2622-3686

Semarak,Vol. 1, No.3,Oktober 2018, Hal (1-20)

@Prodi Manajemen Fakultas Ekonomi Universitas Pamulang melakukan peramalan, sebuah model yang baik adalah model dengan kesalahan peramalan yang seminimal mungkin.

Karena itu, sebuah model sebelum digunakan seharusnya memenuhi asumsi klasik".

a. Pengujian Normality Data.

Pendapat Imam Ghozali (2014) "Model regresi yang baik adalah berdistribusi normal atau mendekati normal". Lebih lanjut dijeaskan "Uji normalitas dapat berpedoman pada uji Kolmogorov Smirnov dengan ketentuan sebagai berikut":

1) Jika nilai probability significancy < 005, disimpulkan data tidak normal.

2) Jika nilai probability significancy > 0.05 , disimpulkan data normal.

\section{b. Pengujian Multicollinierty}

Menurut Ghozali (2014) "Uji

Multikoliniearitas digunakan untuk menguji model regresi ditemukan adanya correlation antar Variable independentt atau tidak". Lebih lanjut dijelaskan "Untuk mendeteksi ada tidaknya multikoliniearitas dalam model regresi dapat dilihat dari tolerance value atau Variance Inflation Factor (VIF) dengan ketentuan sebagai berikut":

1) Apabila toleransi $<1$ serta Varianace Inlation Factor (VIF) < 10, kesimpulan tidak terdapat gangguan multicollinierity.
2)Apabila toleransi $>1$ serta Varianace Inlation Factor (VIF) > 10, kesimpulan terdapat gangguan multicollinierity.

\section{c. Autocorrelation Test.}

Pendapat Ghozali (2014) "Uji autocorrelation bertujuan menguji apakah dalam model regresi liner ada correlation antar kesalahan pengganggu pada periode $t$ dengan kesalahan pengganggu pada periode t-1". Lebih lanjut dijelaskan bahwa dalam penelitian dapat digunakan uji Durbin Waton (DW) test. Uji ini berpedoman pada:

Table Kriteria pengujian Durbin Watson

\begin{tabular}{|c|l|}
\hline \multicolumn{1}{|c|}{$\mid$} & Ada Autocorrelation \\
\hline $1.1-1.540$ & Tanpa kesimpulan \\
\hline $1.550-$ & Terjadi Autocorrelation \\
.2 .460 & \\
\hline $2.460-2.900$ & Tanpa kesimpulan \\
\hline$>2.900$ & Ada Autocorrelation \\
\hline
\end{tabular}

\section{d. Pengujian Heteroskoesdastisitas}

Pendapat Ghozali (2014) "Uji heteroskedastisitas bertujuan untuk mengetahui apakah dalam model regresi terjadi ketidaksamaan varian dari suatu residual pengamatan ke pengamatan lain". Lebih lanjut dijelaskan "Untuk mengetahui ada tidaknya heteroskedastisitas adalah dengan menggunakan uji Glejser", dimana ketentuan sebagai berikut: 
JURNAL

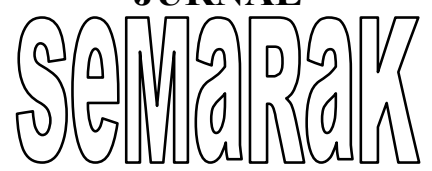

P-ISSN 2615-6849 E-ISSN 2622-3686

Semarak,Vol. 1, No.3,Oktober 2018, Hal (1-20)

@Prodi Manajemen Fakultas Ekonomi Universitas Pamulang
1) Apabila variable independent nilai probability significancy $<0.05$, data terjadi gangguan.

2) Apabila variable independent nilai probability significancy $>0.05$, data tidak ada gangguan.

\section{Analisis Deskroptif dan verifikarif}

\section{a. Analisis Deskriptif}

Menurut Sugiyono (2017) "Skala pengukuran merupakan kesepakatan yang digunakan sebagai acuan untuk menentukan panjang pendeknya interval yang ada dalam alat ukur sehingga alat ukur tersebut bila digunakan dalam pengukuran akan menghasilkan data".

\section{b. Analisis Verifikatif (Inferensial)}

Menurut Sugiyono (2017) "Metode verifikatif merupakan penelitian yang bertujuan untuk mengetahui hubungan antara dua Variable atau lebih".

\section{Regression Linier Sederhana}

Sugiyono (2016) "Analisis regresi liner sederhana dimaksudkan untuk menganalisis hubungan secara parsial antara X terhadap Y”.

\section{Regression Linier Berganda}

Sugiyono (2016) “Analisis regresi berganda untuk menganalisis hubungan dua variabel bebas atau lebih terhadap variabel terikatnya".

\section{3. coefficient Correlation}

Menurut Sugiyono

"coefficient korelasi digunakan untuk mengetahui tingkat hubungan Variable independent terhadap Variable dependent"

Table 2 Pedoman Interpretasi coefficient corelation.

\begin{tabular}{|lr|l|}
\hline $\begin{array}{l}\text { Nilai Interval } \\
\text { Korelasi }\end{array}$ & Keputusan \\
\hline 0.000 & $\mathrm{~s} / \mathrm{d}$ & Sangat rendah \\
0.199 & & \\
\hline 0.200 & $\mathrm{~s} / \mathrm{d}$ & Rendah \\
0.399 & & \\
\hline 0.400 & $\mathrm{~s} / \mathrm{d}$ & Sedang \\
0.599 & & \\
\hline 0.600 & $\mathrm{~s} / \mathrm{d}$ & Kuat \\
0.799 & & \\
\hline 0.800 & $\mathrm{~s} / \mathrm{d}$ & Sangat Kuat \\
1.000 & & \\
\hline
\end{tabular}

\section{4. coefficient Determination (Kd)}

Menurut Sugiyono (2016) "Kefisien coefficient determination digunakan untuk mengetahui berapa persen hubungan variabel bebas terhadap variabel terikat".

\section{Hipotesis Analyisis Test}

a. Partial Test (Single) menggunaka uji t, yaitu untuk mengetahui hubungan antar variabel independen dengan dependen secara satu-satu.

b. Simultant Test menggunaka uji t, yaitu untuk mengetahui hubungan antar variabel independen dengan dependen secara bersaa-sama.

\section{HASIL ANALISIS DATA}

\section{A. Uji Instrument Data Penelitian}

1. Pengujian Validitas 
JURNAL

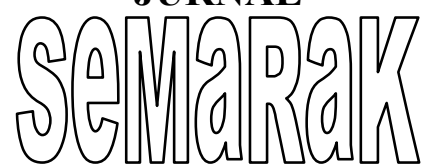

Semarak,Vol. 1, No.3,Oktober 2018, Hal (1-20)

@Prodi Manajemen Fakultas Ekonomi Universitas Pamulang

Table 3 Hasil Uji Validitas Promosi

\begin{tabular}{|l|c|l|l|}
\hline Pertanyaar & Rca & \multicolumn{2}{c|}{ Std. Rca Keterangan } \\
\hline Pert. 1 & 0.372 & 0.300 & Valid \\
\hline Pert. 2 & 0.521 & 0.300 & Valid \\
\hline Pert. 3 & 0.394 & 0.300 & Valid \\
\hline Pert. 4 & 0.568 & 0.300 & Valid \\
\hline Pert. 5 & 0.609 & 0.300 & Valid \\
\hline Pert. 6 & 0.513 & 0.300 & Valid \\
\hline Pert. 7 & 0.580 & 0.300 & Valid \\
\hline Pert. 8 & 0.700 & 0.300 & Valid \\
\hline
\end{tabular}

Variable promosi diperoleh chronbath alpha > standar alpha 0.30 , dengan demikian semua pernyataan disimpulkan valid.

Table 4 Hasil Uji Validitas Variable

Pengembanagn Produk

\begin{tabular}{|l|c|c|c|}
\hline \multicolumn{1}{|c|}{ Pertanyaan } & \multicolumn{2}{|c|}{ Rca } & Std. Rc: \\
\hline Pert. 1 & 0.397 & 0.300 & Valid \\
\hline Pert. 2 & 0.524 & 0.300 & Valid \\
\hline Pert. 3 & 0.413 & 0.300 & Valid \\
\hline Pert. 4 & 0.840 & 0.300 & Valid \\
\hline Pert. 5 & 0,539 & 0.300 & Valid \\
\hline Pert. 6 & 0.440 & 0.300 & Valis \\
\hline Pert. 7 & 0.709 & 0.300 & Valid \\
\hline Pert. 8 & 0.407 & 0.300 & Valid \\
\hline
\end{tabular}

Berdasarkan data pada Table di atas, Variable pengembangan produk diperoleh Chronbatch Alpha > Standar Alpha 0.300, dengan demikian semua pernyataan disimpulkan valid.

Table 5 Hasil Uji Validitas Variable Peningkatan Hasil Penjualan

\begin{tabular}{|l|c|c|c|}
\hline \multicolumn{2}{|c|}{ Pertanyaan } & Rca & Std. Rc: Keputusar \\
\hline Pert.1 & 0.565 & 0.300 & Valid \\
\hline Pert.2 & 0.489 & 0.300 & Valid \\
\hline Pert.3 & 0.539 & 0.300 & Valid \\
\hline Pert.4 & 0.450 & 0.300 & Valid \\
\hline Pert.5 & 0.491 & 0.300 & Valid \\
\hline Pert.6 & 0.588 & 0.300 & Valid \\
\hline Pert.7 & 0.684 & 0.300 & Valid \\
\hline Pert.8 & 0.481 & 0.300 & Valid \\
\hline
\end{tabular}

Berdasarkan data pada Table di atas, Variable peningkatan hasil penjualan diperoleh Chronbatch Alpha $>$ Standar Alpha 0.300, dengan demikian semua pernyataan disimpulkan valid.

\section{Hasil Pengujian Reliabilitas Data}

Table 6. Hasil Pengujian Reliabilitas.

\begin{tabular}{|l|c|c|c|}
\hline Variable & \multicolumn{1}{c}{ Rca } & \multicolumn{2}{c|}{ Std. Rca|Keputusal } \\
\hline Variable & 0.627 & 0.600 & $\begin{array}{c}\text { Reliabl } \\
\mathrm{e} \\
\text { X1 }\end{array}$ \\
Variable X2 & 0.512 & 0.600 & $\begin{array}{c}\text { Reliabl } \\
\mathrm{e} \\
\text { Variable Y }\end{array}$ \\
0.516 & 0.600 & $\begin{array}{c}\text { Reliabl } \\
\mathrm{e}\end{array}$ \\
\hline
\end{tabular}

Diperoleh Chronbatch Alpha

Standar Alpha 0.600 dimana an nilai rca bernilai positive, dengan demikian maka semua pernyataan pada Variable yang dipakai disimpulkan reliabel.

\section{B. Pengujian Kelayakan Data}

\section{Pengujian Normality Test Data}

Sugiyono (2016) "Uji normalitas dilakukan untuk menguji apakah dalam model regresi, antara variable dependentt \& variable independentt memiliki distribusi normal atau tidak".

Table 7 Hasil Normality Test dengan (Kolmogorof Smirnov Test)

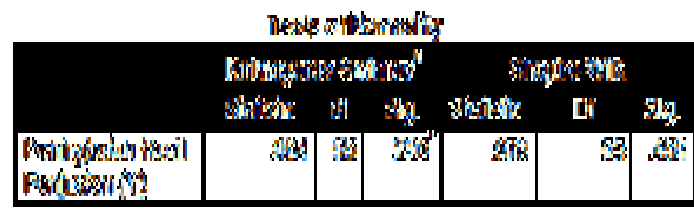

Berdasarkan data di atas diperoleh Probability significancy 0.200 , Nilai tersebut $>0.050$. Dengan demikian data 


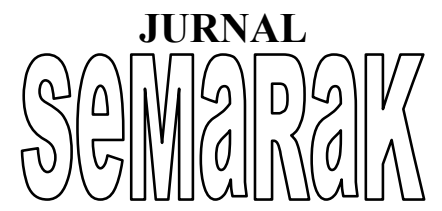

Semarak,Vol. 1, No.3,Oktober 2018, Hal (1-20)

@Prodi Manajemen Fakultas Ekonomi Universitas Pamulang

memenuhi unsur normal dan layak untuk diteruskan.

\section{Pengujian Multicolinierity}

$$
\text { Pengujian multikolinierity }
$$

berpedoman pafa nilai Tolerance Value dan Variance Inflation Factor.

Table 8. Hasil Uji Collinierity Statistic.

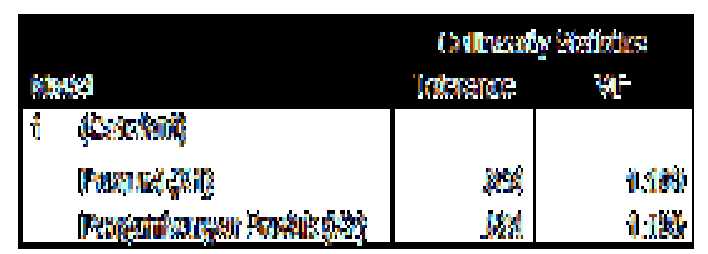

Diperoleh nilai Tolerance $0.834<$ 1,0 dan nilai VIF $1,199<10$, dengan demikian model regresi ini tidak ada gangguan multikolinearitas.

\section{Autocorrelation Test.}

Table 9 Hasil Aurocorrelation Test

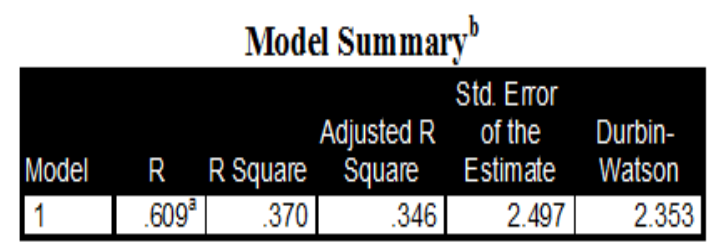

Durbin Watson test diperoleh nilai 2.353 berada pada interval 1.440-2.460. Disipmulkan data tidak memiliki penyimpangan authocorelations.

\section{Pengujian Heteroskesdastisitas.}

Dalam penelitian ini menggunakan Glejser test model. Hasilnya sebagaiberikut:

Table 10. Hasil Glejser Test Model.

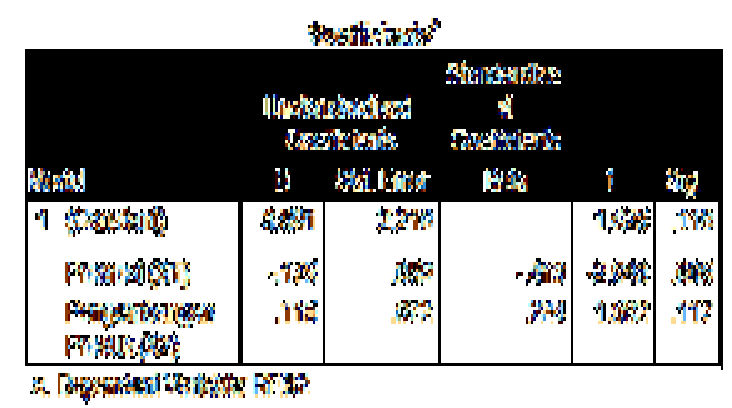

Constanta probability Significancy senilai $0.110>0.050$. Oleh karenanya data pada model regresi layak diteruskan sebagai data penelitian.

\section{Analyisis Verifikatif}

\section{Analisis Regresi Berganda}

Table 11. Hasil Uji Regression Multiple

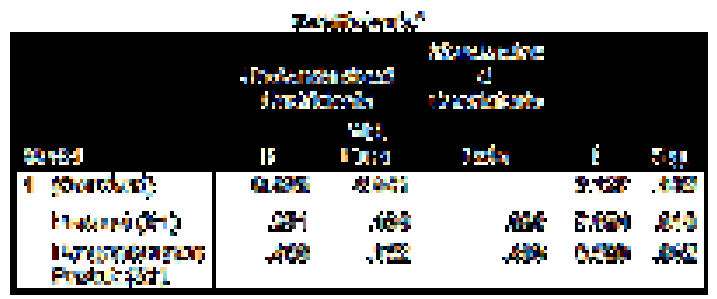

Diperoleh persamaan regresinya sebesar $\mathrm{Y}$ $=8.595+0.291 \mathrm{X} 1+0.438 \mathrm{X} 2$. Pnjelasan dari persamaan ini sebagai berikut:

a. Constanta 8.595 , artinya apabila variable X1 dan X2 konstant, maka sudah terbentuk nilai Y sebesar 8.595\%.

b. Variable Promosi memiliki hubungan positive dan significant terhadap peningkatan hasil penjualan dengan coeficien betta sebesar 0.291. artinya jika promosi meningkat maka hasil penjualan akan meningkat 1 satuan dengan asumsi bahwa pengembangan produk konstan. 
JURNAL

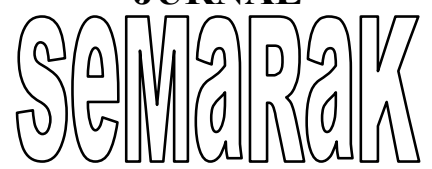

Semarak,Vol. 1, No.3,Oktober 2018, Hal (1-20)

@Prodi Manajemen Fakultas Ekonomi Universitas Pamulang

c. Variable Pengembangan produk berhubungan positive dan significant terhadap peningkatan hasil penjualan, nilai coeficien betta 0.438 . artinya jika product development meningkat 1 satuan maka hasil penjualan juga akan meningkat dengan asumsi promosi konstan.

\section{3. coefficient Correlation Analysis.}

Table 12.Hasil Pengujian correlation hubungan promosi (X1) Terhadap Peningkatan Hasil Penjualan (Y).

\begin{tabular}{|c|c|c|c|}
\hline & & Trammal (1\%1) & $\begin{array}{c}\text { Raningkiton } \\
\text { has panyalan } \\
\text { py }\end{array}$ \\
\hline Fiưrida $\mid \mathrm{X} I\}$ & 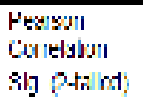 & 1 & $\begin{array}{r}40 i \\
0.3\end{array}$ \\
\hline 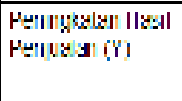 & 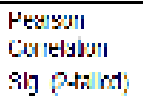 & $.40 \%$ & I \\
\hline
\end{tabular}

Berdasarkan data di atas, diperoleh nilai correlation sebesar 0.487. Artinya kedua variabel memiliki tingkat hubungan yang sedang.

Table 13.Hasil Pengujian correlation hubungan Pengembangan Produk (X2) Terhadap Hasil Penjualan (Y)

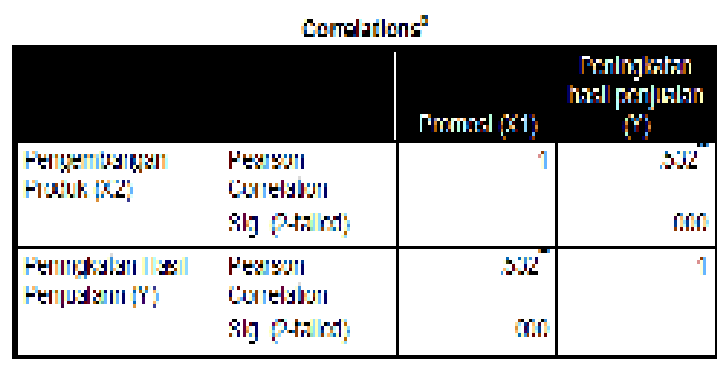

Berdasarkan data di atas, diperoleh nilai correlation 0.532 . Artinya kedua variabel memiliki tingkat kekuatan hubungan yang sedang.

Table 14.Hasil Uji Correlation dari Promosi (X1) dan Pengembangan Produk (X2) Terhadap Hasil Penjualan (Y) Secara Simultan.

\begin{tabular}{|l|r|r|r|r|}
\multicolumn{5}{c}{ Model Summary } \\
\hline \multicolumn{9}{|c|}{ Model } & R & \multicolumn{3}{c|}{ R Square } & Squsted R & $\begin{array}{r}\text { Std. Error of } \\
\text { the Estimate }\end{array}$ \\
\hline 1 & $.609^{3}$ & .370 & .346 & 2.497 \\
\hline
\end{tabular}

Berdasarkan data di atas, diperoleh nilai correlation sebesar 0.609 , artinya ketiga variabel secara simultan memiliki tingkat hubungan yang Kuat.

\section{Analisis coefficient Determination.}

Tabel 15. Koefisien coefficient determination Hasil Uji hubungan Promosi (X1) Terhadap Hasil Penjualan (Y)

\begin{tabular}{|c|c|c|c|c|}
\hline \\
\hline Model & $\mathrm{R}$ & R Square & $\begin{array}{l}\text { Adjusted R } \\
\text { Square }\end{array}$ & $\begin{array}{l}\text { Std. Error of } \\
\text { the Estimate }\end{array}$ \\
\hline 1 & & 237 & .222 & 2.723 \\
\hline
\end{tabular}

Nilai $R$ Square didapat 0,237 . Hal ini menunjukkan bahwa hubungan promosi terhadap peningkatan hasil penjualan adalah $23,7 \%$, sedangkan sisanya $76,3 \%$ dihubungani oleh faktor lain.

Tabel 16. Hasil Uji Penentuan hubungan Pengembangan Produk (X2) pada Hasil Penjualan (Y).

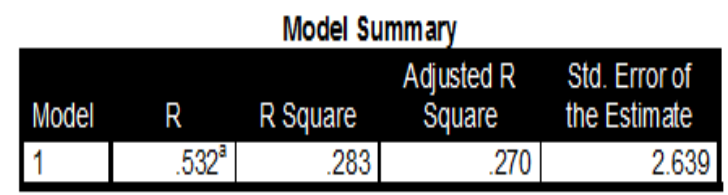




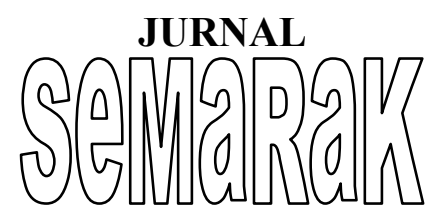

\section{P-ISSN 2615-6849 E-ISSN 2622-3686}

Semarak,Vol. 1, No.3,Oktober 2018, Hal (1-20)

@Prodi Manajemen Fakultas Ekonomi Universitas Pamulang
Dipreoleh nilai $R$ Square sebesar 0.285 .

Artinya kontribusi pengaruh dari pengembangan produk terhadap hasil penjualan sebesar $28.3 \%$

Tabel 17. Uji coefficient Determination Variable Promosi (X1) dan Pengembangan Produk (X2) Terhadap Peningkatan Hasil Penjualan

(Y).

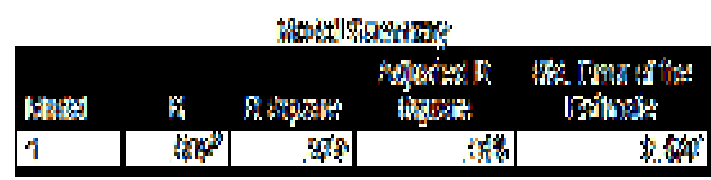

Nilai coefficient determination yang diperoleh adalah 0.370. Hal ini menunjukkan bahwa hubungan promosi (X1) dan pengembangan produk (X2) secara bersamaan adalah 37,0\%, sedangkan sisanya $63,0 \%$ dipengaruhi oleh faktor lain.

\section{Hipotesis Test Analysis.}

a. Hipotesis Parsial

Rumusan:

Terdapat pengaruh yang positive dan Significant antara promosi terhadap peningkatan hasil penjualan.

Tabel 18 Output Hipotesis Pertama.

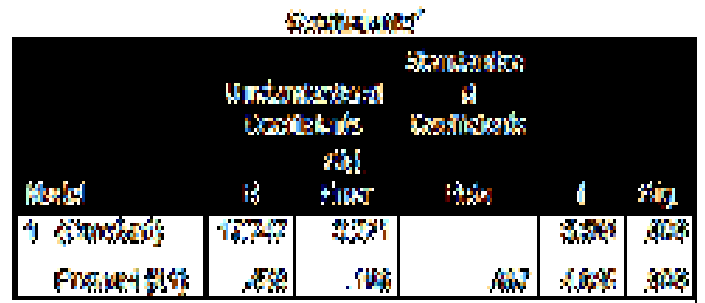

Berdasarkan output data di atas, diperoleh nilai probability significancy
$0,000<0,050$ dengan demikian hipotesis pertama diterima.

Rumusan:

Terdapat pengaruh positive dan significant antara pengembangan produk terhadap peningkatan haeil penjualan.

Tabel 19 Output Hipotesis Kedua.

\begin{tabular}{|c|c|c|c|c|c|}
\hline band & 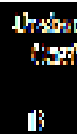 & 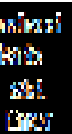 & 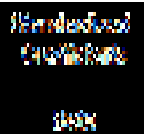 & $i$ & 84 \\
\hline 1 truenst: & 12: & 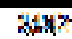 & & 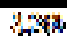 & $x \notin$ \\
\hline 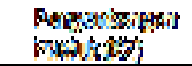 & 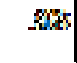 & $A^{\prime} 18 z$ & 촌 & $42 \pi$ & 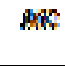 \\
\hline
\end{tabular}

Berdasarkan output data, diperoleh nilai probability significancy $0.000<0.05$. Dengan demikian hipotesis kedua diterima.

\section{b. Uji Hipotesis (ANOVA)}

Rumusan:

Terdapat pengaruh positive dan significant antara promosi dan pengembangan produk terhadap peningkatan hasil penjualan.

Tabel 20 Output Hipotesis ketiga.

\begin{tabular}{|c|c|c|c|c|c|}
\hline \multicolumn{6}{|c|}{ (K) } \\
\hline 60 & 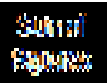 & $\mathrm{X}^{\prime \prime}$ & $\begin{array}{l}\text { Bowh } \\
\text { Equation }\end{array}$ & i & 政存。 \\
\hline 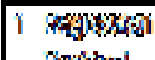 & Wods & zi & 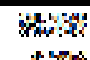 & 10x & $m a y^{4}$ \\
\hline Awenal & \&ES & $M$ & $\mathrm{i}+270$ & & \\
\hline Whis & 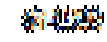 & 13 & & & \\
\hline
\end{tabular}

Berdasarkan output data, diperoleh probability significancy $0.000<0.05$, dengan demikian hipotesis ketiga diterima. 


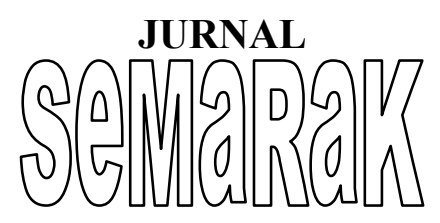

P-ISSN 2615-6849 E-ISSN 2622-3686

Semarak,Vol. 1, No.3,Oktober 2018, Hal (1-20)

@Prodi Manajemen Fakultas Ekonomi Universitas Pamulang

\section{HASIL DAN PEMBAHASAN}

1. Hubungan Promosi (X1) Secara

Parsial Terhadap Peningkatan Hasil

Penjualan (Y).

Persamaan regresi diperoleh $\mathrm{Y}=17,747+$ $0,438 X 1$. Konstansta memiliki nilai positive sehingga jika promosi meningkat, maka peningkatan hasil penjualan juga akan meningkat. Analisis koefisien correlation diperoleh nilai 0,487 yang berarti variable promosi memiliki hubungan positive, Tingkat kekuatan hubungannya adalah sedang. Nilai coefficient determination (Kd) diperoleh 0,237 , yang berarti bahwa variabel promosi memberikan kontribusi $23,7 \%$ terhadap peningkatan hasil penjualan. Pengujian hipotesis parsial diperoleh probability significancy $0.000<0.050$ artinya hipotesis pertama diterima.

\section{Hubungan Pengembangan Produk} (X2) Secara Parsial Terhadap Peningkatan Hasil Penjualan (Y).

Persamaan regresi diperoleh $\mathrm{Y}=12,770+$ $0,583 \mathrm{X} 2$. Konstansta memiliki nilai positive sehingga jika pengembangan produk meningkat, maka akan meningkatkan hasil penjualan akan lebih optimal. Analisis koefisien correlation memperoleh nilai 0,532 , yang berarti bahwa kedua Variabel memiliki hubungan positive dengan tingkat hubungan yang sedang dengan kontribusi hubungan sebesar $28.30 \%$ untuk meningkatkan hasil penjualan. Uji hipotesis diperoleh nilai probability significancy $0.000<0.05$ artinya

hipotesis $\mathrm{H} 2$ dapat diterima.

\section{Hubungan Promosi (X1) dan Pengembangan Produk (X2) Secara Bersamaan Melawan Peningkatan Hasil Penjualan (Y).}

Persamaan regresi diperoleh $\mathrm{Y}=8,595+$ $0,291 X 1+0,438 X 2$. Konstansta memiliki nilai positive sehingga jika promosi dan pengembangan produk bersaing, maka peningkatan hasil penjualan akan meningkat. Nilai correlation 0,609 berarti bahwa ketiga Variabel memiliki hubungan positive 0,690 dengan kontribusi pengaruhnya sebesar $37 \%$ sedangkan sisanya sebesar $(100-37 \%)=63 \%$. Pengujian hipotesis dengan ANOVA test diperoleh probability signifiancy $0000<0.05$ dengan demikian $\mathrm{H} 3$ diterima.

\section{KESIMPULAN DAN SARAN.}

\section{A. kesimpulan}

1. Variable promosi berpengaruh positif dan signifikan terhadap peningkatan hasil penjualan dengan determination sebesar $33.7 \%$. Uji hipotesis parsial nilai probability significancy $\quad 0.000<0.05$ artinya hipotesis pertama (H1) diterima.

2. Variabel Pengembangan produk memiliki hubungan positive dan significant terhadap peningkatan hasil penjualan dengan kontribusi $28.30 \%$. Pengujian hipotesis diperoleh nilai probability 


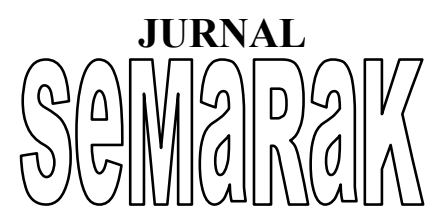

P-ISSN 2615-6849 E-ISSN 2622-3686

Semarak,Vol. 1, No.3,Oktober 2018, Hal (1-20)

@Prodi Manajemen Fakultas Ekonomi Universitas Pamulang

significancy $0.000<0.05$ sehingga $\mathrm{H} 2$ diterima.

3. Variable promosi dan pengembangan produk secara simultan memiliki hubungan positive dan significant terhadap peningkatan hasil penjualan dengan kontribusi sebesar $37.0 \%$. Pengujian hipotesis diperoleh nilai probability significancy $0.000<0.05$ dengan demikian hipotesis ketiga (H3) diterima.

\section{B. Saran}

1. Variable promosi, indikator yang paling lemah ada pada personal selling, dimana hanya memperoleh skor 3,62. Perusahaan harus mengoptimalkan pemasarnya strategi pendekatan customer yang lebih efektif.

2. Variable pengembangan produk, indikator yang paling lemah ada pada kualitas produk, dimana hanya memperoleh skor 3,76. Perusahaan harus memilih bahan baku yang lebih baik sehingga out put produk memiliki kualitas baik.

3. Variable peningkatan hasil penjualan indikator yang paling lemah ada pada penyampaian informasi produk dimana hanya memperoleh skor 3,64. Perusahaan harus aktif mencari pasar baru.

4. hubungan secara simultan sebesar $37,0 \%$, nilai ini masih bisa ditingkatkan dengan cara perusahaan harus menerapkan strategi promosi yang lebih efektif dan sering melakukan riset pasar yang erat kaitannya dengan produk yang lebih siminati pasar sasaran.

\section{DAFTAR PUSTAKA}

Abdullah, Thamrin dan Tantri, Francis, Manajemen Pemasaran, Edisi 1, Jakarta: Rajawali Pers, 2013.

Adi Sismanto. 2006, Analisis Pengaruh Orientasi Pembelajaran, Promosi dan Inovasi Terhadap Keunggulan Bersaing Untuk Meningkatkan Peningkatan hasil penjualan Tesis. Universitas Diponegoro, Semarang.

Algifari, 2010, Analisis Regresi, Teori, Kasus dan Soluysi. Edisi kedua. Yogyakarta: BPFE UGM.

Alma, Buchori, 2009. Manajemen Pemasaran \& Pemasaran Jasa, Bandung: CV. Alfabetha.

Anggipora, M. P., 2002. Dasar-Dasar Pemasaran, Edisi Revisi, Cetakan Kedua, Penerbit PT. Raja Grafindo Persada, Jakarta. Jurnal Ilmu dan Riset Manajemen, Volume 1 Nomor 1, Januari 2013: 25-46.

Arikunto, Suharsimi, 2010. Prosedur Penelitian Suatu Pendekatan Praktek. Jakarta: PT.Rineka Cipta.

Freeman, R.E. 2004. A Stakeholder Theory of Modern Corporations, Ethical Theory and Business, 7th ed.

Hasan, Ali. 2013. Marketing, Yogyakarta: Media Utama.

Imam Ghozali, Imam. 2013, Aplikasi Analisis Multivariate dengan Program SPSS. Edisi Kelima. Semarang: Badan Penerbit Undip.

Keller dan Amstrong. 2014. Prinsip-prinsip Pemasaran. Edisi Kedua Belas. Jakarta: Erlangga. 


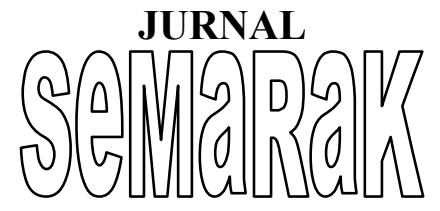

P-ISSN 2615-6849 E-ISSN 2622-3686

Semarak,Vol. 1, No.3,Oktober 2018, Hal (1-20)

@Prodi Manajemen Fakultas Ekonomi Universitas Pamulang

Kotler dan Keller. 2012. Manajemen Pemasaran. Jakarta: PT Macaman Jaya Cemerlang.

Zamit, Yulian. 2013. Manajemen Kualitas Produk \& Jasa. Yogyakarta. Ekonisia.

Kotler, Philip and Garry Amstrong. 2012. Principles of Marketing. New Jersey: Pearson Education Limited. Jurnal Riset Manajemen Sains Indonesia (JRMSI) |Vol.

Umar, Husein, "Riset Pemasaran dan Perilaku Konsumen”, Gramedia Pustaka Utama, Jakarta, 2010

3, No. 1, 2012.

Kotler. 2012, Manajemen Pemasaran, Edisi Keempat belas, PT. Indeks, Jakarta.

Rangkuti, Freddy. 2009. Strategi Promosi Yang Kreatif, Jakarta: Gramedia Pustaka Utama.

Sampurno. 2010. Manajemen Stratejik:Menciptakan Keunggulan Bersaing yang Berkelanjutan. Yogyakarta: Gadjah Mada University Press.

Sarwono, Jonathan. 2012. Metode Penelitian Kuantitatif Dan Kualitatif. Yogyakarta: Graha Ilmu.

Simamora, Bilson. 2012. Panduan Perilaku Pelanggan. Jakarrta: Penerbit PT. Gramedia Pustaka Utama.

Soehardi Sigit. 1992. Marketing Praktis.Penerbit Armirrita: Yagyakarta.1992. Marketing,jilid 1. PenerbitErlangga: Jakarta.

Sugiyono. 2014. Metode Penelitian Kuantitatif Kualitatif dan $R \& D$. Penerbit CV. Alfabeta. Bandung.

Swastha, Bashu dan T. Handoko. 2008. Manajemen Pemasaran Moderen. Yogyakarta: BPFE.

Tjiptono, Fandy dan Chandra Gregorius. 2012. Service, Quality dan Satisfaction, Edisi Ketiga. Yogyakarta : Pustaka Andi.

Wiliam J. Stanton. 2010. Prinsip-Prinsip Pemasaran. Edisi ketujuh. Jakarta: Erlangga. 